\title{
KRAŠTOVAIZDŽIO, KAIP REKREACINĖS APLINKOS, PRIEINAMUMO REGLAMENTAVIMO LIETUVOJE IR UŽSIENIO VALSTYBĖSE ANALIŻ்
}

\author{
Dovilè Dimindavičiūtė \\ KTU Architektūros ir statybos institutas, Tunelio g. 60, LT-44405 Kaunas, Lietuva \\ El.paštasdodimi@gmail.com \\ Iteikta 20081014
}

\begin{abstract}
Santrauka. Straipsnyje nagrinėjamos visuomenès teisès laisvai judèti ir užsiimti rekreacine veikla atvirame, neužstatytame kraštovaizdyje Lietuvoje ir užsienio valstybėse. Šiuo metu Lietuvoje tokios universalios teisès, įtvirtintos įstatymuose, nẻra, nors kartu nẻra ir giežtų draudimų būti ir judèti atvirame kraštovaizdyje. Tačiau žemès, miškų ir vandenų ūkio žemių privatizavimas ir savininkų noras kuo labiau apriboti savo žemes vis labiau mažina visuomenès teises į Lietuvos kraštovaizdị. Straipsnyje apibendrinama šiuo metu galiojanti teisinè bazé, reglamentuojanti Lietuvos visuomenès teises ị atvirą kraštovaizdị. Pateikiama užsienio valstybių patirtis šioje srityje. Tai skandinaviškas ir škotiškas modelis, kur galioja universali prieigos teisè. Palyginimui kaip kontrastas pateikiamas Anglijos ir Velso modelis, kur visuomenès teisès ị atvirą kraštovaizdị labai ribotos. Apibendrinus esamą situaciją Lietuvoje ir užsienio patirtị, straipsnyje siūloma ir Lietuvoje ịstatymu užtikrinti visuomenei kraštovaizdžio prieinamumą.

Reikšminiai žodžiai: prieigos teisé, kiekvieno žmogaus teisė, kelio teisė, rekreacija atvirame ore, atviras kraštovaizdis, rekreacinės teritorijos, prieigos prie vandens telkinių pakrančių.
\end{abstract}

\section{Ivadas}

Europoje teisè keliauti atviru kraštovaizdžiu ${ }^{1}$ - visomis tomis vietomis, kurios nebuvo apstatytos ir aptvertos, iki pat moderniujų laikų buvo nekvestionuojama. Šiais laikais yra priešingai - egzistuoja daugybè ịstatymų, ribojančių laisvą judèjimą tiek privačia, tiek valstybine žeme. Tačiau Europoje yra valstybių, kur senovinè paprotinè teise judèti atviru kraštovaizdžiu yra perkelta i ịstatymus, o ja gali naudotis tiek tų valstybių piliečiai, tiek ir atvykę i šalị svečiai.

Lietuvoje per paskutinius du dešimtmečius atviro kraštovaizdžio prieinamumo rekreacijai problema tampa vis aktualesnè. Nuo seno visiems įprastose rekreacinėse teritorijose prie vandens telkinių nutisso tvoros, pakrantèse pridygo pirčių ir vasarnamių bei skelbimų privati valda vidury miškų. Daug žmonių, metų metais pripratę su šeimomis lankytis ịprastose maudynių vietose, buvo iš jų išstumti. Lietuvos žiniasklaidoje būtent tvorų prie vandens telkinių problema aptariama dažniausiai tiek respublikinejje, tiek vietinejje spaudoje ir internetinejje žiniasklaidoje, tai rodo didžiulį šios problemos aktualumą visuomenei.

\footnotetext{
${ }^{1}$ Atviru kraštovaizdžiu šiame straipsnyje vadinamas neurbanizuotas ir žemès ūkyje intensyviai nenaudojamas kraštovaizdžis.
}

Profesionaliojoje ir mokslinèje spaudoje daugiau dèmesio skiriama rekreacijai ir jos teritorinio planavimo aspektams, rekreaciniams želdynams bei rekreacinei architektūrai. K. Jakovlevas-Mateckis (2006), V. Stauskas (2006), L. Dringelis $(2001,2003)$ savo straipsniuose ne kartą analizavo želdynų, kurie tenkina miesto gyventojų kasdienius rekreacinius poreikius, planavimo ir apsaugos nuo privatizavimo problemas. Kiti Lietuvos mokslininkai ir architektūros specialistai nagrinëjo rekreacinio kraštovaizdžio bei rekreacinès architektūros klausimus. Čia minètini P. Grecevičiaus ir bendraautorių straipsniai (Grecevičius 1998; Grecevičius, Marčius 2006), skirti Lietuvos pajūrio rekreaciniam kraštovaizdžiui, J. Tutlytès (2000) straipsnis, skirtas rekreacinei architektūrai vertinti, A. Mačerinskienès (2001) straipsnis, skirtas turizmo traukos potencialo analizei.

Tačiau apie universalias teises ị atvirą kraštovaizdi išsamiai nebuvo diskutuojama nei mokslinèje spaudoje, nei dienraščiuose. Todèl šiame straipsnyje siekiama išnagrinèti, kokias dabar teises judèti ir užsiimti rekreacine veikla atvirame kraštovaizdyje turi Lietuvos gyventojai. Čia remiamasi LR įstatymais ir nuostatais bei Baudžiamuoju kodeksu. Teisinè situacija Lietuvoje lyginama su Skandinavijos valstybių ir Škotijos, kur galioja prieigos teisè, situacija. Išryškinami šių šalių prieigos 
teisių panašumai ir skirtumai, parodoma, kaip derinami viešieji ir privatūs interesai.

Kaip priešingas pavyzdys apžvelgiamos kraštovaizdžio prieigos galimybès Anglijoje ir Velse - šalyse, kur privatūs interesai yra iškelti aukščiau už visuomeninius.

Pagrindiniai šio straipsnio literatūros šaltiniai yra minètų valstybių įstatymų vertimai ị anglų kalbą, taip pat naudotasi oficialia informacija, kuri pateikta ịvairių valstybinių tų šalių institucijų interneto svetainėse. Straipsnyje pateikiami pasiūlymai, kokia prieigos teisè galètų būti ịtvirtinta Lietuvos ịstatymuose.

\section{Teisinės Lietuvos kraštovaizdžio visuomeninio prieinamumo galimybès}

Lietuvoje dauguma žmonių yra linkę laikyti, kad mūsų kraštovaizdis yra viešasis išteklius. Šiuo požiūriu mūsų mentalitetas yra panašus ị skandinavų - apie tai rašoma kitame šio straipsnio skyrelyje. Yra visai įprasta laisvu laiku rekreaciniais tikslais vykti ị miškus ir prie vandens telkiniu pakrančių, lankytis kaimo vietovèse ir pan. Tačiau šis naudojimasis kraštovaizdžiu rekreacijai šiuo metu patiria vis didesnị spaudimą - visuomenè praranda vis daugiau rekreaciniu požiūriu svarbių vietovių.

Dabar mes neturime aiškiai įstatyme užfiksuotos universalios prieigos teisès ị kraštovaizdį, kur galètume užsiimti tokia rekreacine veikla atvirame ore kaip pasivaikščiojimai, iškylavimas, stovyklavimas, sportas ir žaidimai, judejjimas bevarikliu transportu bei jodinèjimas ir pan. Kita vertus, nèra ir aiškaus draudimo judèti privačia žemès ūkio ar miškų ūkio paskirties žeme bei lauko keliais. Pagal LR Baudžiamaji kodeksą (2000) neteisètas yra tik įsibrovimas $\mathfrak{i}$ kito žmogaus gyvenamajj būstą ir saugomą būsto teritoriją (suprask - kiemą).

Nuostatos, panašios i kraštovaizdžio prieigos teisę, yra pateiktos tik Mišku istatyme (2001) ir Žemes įstatyme (2004) (kabant apie vandens telkinių pakrantes ir paveldo objektus).

Remiantis Mišku įstatymu, kiekvienas žmogus Lietuvoje turi teisę laisvai lankytis miškuose, išskyrus rezervatų ir specialios paskirties objektų (pasienio zona, kariniai objektai ir kt.) miškus. Galima rinkti vaisius ir vaistažoles, grybauti ir uogauti. Lankytis miške gali uždrausti tik valdžios institucijos, kai yra labai rimtas pagrindas (didelis gaisringumas, vyksta kirtimai ir pan.), tačiau nei šiame įstatyme, nei kituose nieko nèra pasakyta apie galimybes stovyklauti.

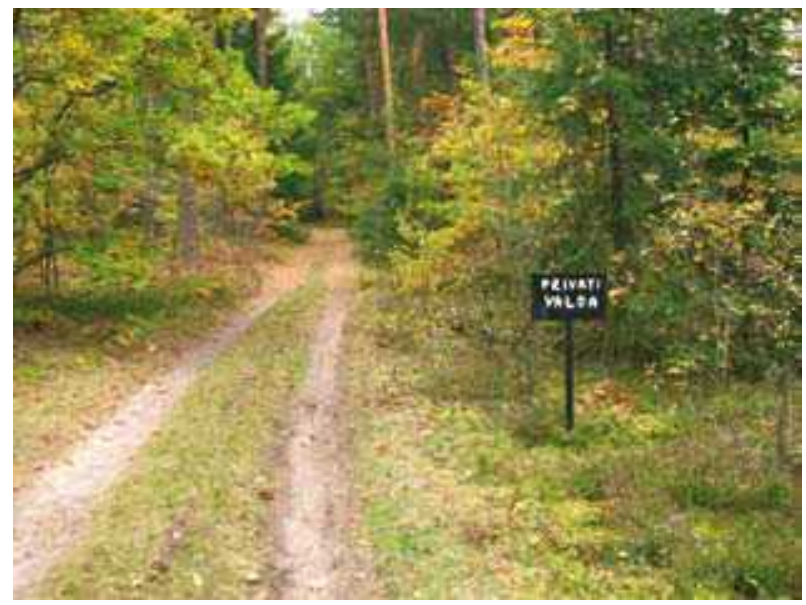

1 pav. Ženklas Privati valda vidury miško - dažnas ir klaidinantis reiškinys dabartinejje Lietuvoje (aut. M. Kavaliauskas) Fig. 1. Misleading sign "Private" in the middle of a forest common sight in Lithuania nowadays. (Photo by M. Kavaliauskas)

Žemes įstatyme nustatyta (IV skyrius, 21 straipsnis, 10 punktas), kad žemès savininkai ir naudotojai privalo leisti kitiems asmenims prieiti prie vandens telkinių nustatytomis pakrantès apsaugos juostomis, lankyti gamtos ir kultūros paveldo teritorinius kompleksus bei objektus ir bendro naudojimo rekreacinius objektus (teritorijas). Specialiosiose žemès ir miško naudojimo salygose (1992) pasakyta, kad vandens telkinių pakrantès apsaugos juostose draudžiama statyti statinius ir tverti tvoras.

Žemes įstatyme yra visas 23 straipsnis, skirtas servitutams, tarp jų ir tiems, kurie suteikia teisę prieiti ir privažiuoti prie rekreacinių teritorijų, paveldo objektų ir bendro naudojimo teritorijų. Tačiau tokių servitutų nustatymas - sudètinga ir ilga procedūra, jei eilinis pilietis norètų kaip nors ją pradèti ir paveikti - turètų turèti labai daug specialių žinių ir laisvo laiko.

Dabartinis Turizmo įstatymas (2002) reglamentuoja daugiausiai turizmo paslaugų teikimą ir valdžios institucijų atsakomybę šioje srityje, o ne Lietuvos kraštovaizdžio prieinamumą. Su nagrinejjama tema siejamas Turizmo įstatymo skirsnis yra apie turizmo išteklius. Tokie gamtos ištekliai kaip miškai, želdynai, vandens telkiniai ir jų pakrantès priskiriami rekreaciniams ištekliams. Rekreacinių išteklių naudotojais visuomenès ir verslo tikslais gali būti fiziniai ir juridiniai asmenys, teikiantys poilsio, reabilitacines ir turizmo paslaugas kažkodèl nepasakyta, kad pati visuomenè gali naudotis rekreaciniais ištekliais tiesiogiai.

Istatyme pateiktas ir rekreacinių teritorijų apibrèžimas - tai vietové, turinti gamtines ar kultūrines aplinkos 
savybes ir sąlygas visaverčiam fiziniam bei dvasiniam žmonių poilsiui organizuoti. Šios teritorijos nustatomos ir planuojamos remiantis teritorijų planavimo dokumentais. Rekreacinių teritorijų naudojimo ir apsaugos priežiūrą vykdo savivaldybių institucijos, vadovaudamosi istatymais bei Rekreaciniu teritoriju naudojimo, planavimo ir apsaugos nuostatais (2004). Rekreacinèse teritorijose draudžiama veikla, galinti pabloginti rekreacinių išteklių būklę ir kelianti pavojų asmenų saugumui ir poilsio organizavimui.

Minètuose nuostatuose dar patikslinamas rekreacinių teritorijų apibrèžimas - jų ribos, žemès naudojimo būdas ir pobūdis yra nustatytas, rekreacinio naudojimo prioritetas suteiktas teritorijų planavimo dokumentais ar teisès aktais. Rekreacinėms vietovėms priklauso kurortai, gyvenamųjų vietovių želdinai, IIB grupès (rekreaciniai) miškai, vandens telkiniai, bendraisiais planais priskirti rekreaciniams ištekliams.

Rekreacinès teritorijos gali būti tiek valstybinès, tiek privačios nuosavybès formos žemèje. Visuomeniniu požiūriu svarbiausi šių nuostatų punktai yra tie, kuriuose pasakyta, kad rekreacinèse teritorijose draudžiama trukdyti lankyti rekreacijai naudojamas teritorijas bei objektus, trukdyti ilsètis poilsiui skirtose vietose, jose galima keliauti pèsčiomis, rinkti miškuose vaistažoles, riešutauti, uogauti ir grybauti, maudytis visuose paviršinio vandens telkiniuose, prieiti prie šių telkinių pakrantès juostomis, taip pat kitaip naudotis privačiais vandens telkiniais servitutų nustatyta tvarka, plaukioti plaukiojimo priemonėmis be vidaus degimo ir elektros variklių pratakiuose paviršinio vandens telkiniuose, žvejoti.

Rekreaciniu teritoriju naudojimo, planavimo ir apsaugos nuostatų teiginiai iš pirmo žvilgsnio tarsi suteikia plačias teises žmonèms lankytis atvirame kraštovaizdyje. Tačiau nèra taip gerai, kaip atrodo. Žmogus negali laisvai nuspręsti, kas jam pačiam yra rekreacinè teritorija. Tai sprendžia valdininkai ir profesionalūs planuotojai, dažniausiai rengdami savivaldybių bendruosius planus ir valstybinių parkų planavimo schemas. Jie turi teisę nuspręsti ir pažymèti rekreacines teritorijas planuose. Natūralu, kad kokios nors palaukès ar upeliūkščio nepažymès kaip rekreacinès teritorijos. Tačiau ta vieta pakeliauti gali panorèti koks nors LR pilietis, ypač jei jis nenori leisti laisvalaikio "rekreaciniuose getuose“ teritorijose, kurios per daug intensyviai lankomos.

Lietuvos kraštovaizdis yra toks, kad nubrèžti griežtas ribas, kur tiksliai baigiasi rekreacinè teritorija, nèra ịmanoma. Pvz., Suvalkija nepasižymi aukščiausios kokybès gamtiniais rekreaciniais ištekliais, tokiais kaip ežerin- gos Aukštaitijos kalvos. Iš 328 Lietuvos kaimo turizmo sodybų tik 13 yra Suvalkijoje (Lietuvos kaimo turizmo asociacijos interneto svetainès duomenys). Tačiau yra nemažai žmonių, kurie tame krašte mielai važiuoja ị žygius dviračiais ar užsiimia kita mègstama rekreacine veikla. Ir žmonès, nedirbantys teritorijų planavimo srityje, tikrai nepradès ieškoti atitinkamų teritorijų planavimo dokumentų ir nesiaiškins, kur planuotojai pažymejo rekreacines teritorijas.

Taigi galimybę užsiimti rekreacija atvirame ore Rekreaciniu teritoriju naudojimo, planavimo ir apsaugos nuostatai daugiau apriboja, o ne išplečia.

Kartu Lietuvos ịstatymuose niekur neparašyta, kad turi būti sudaryta galimybè prieiti iki vandens telkinių. Kas iš tos teises vaikščioti pakrantės apsaugos juosta, jei iki vandens telkinio nèra jokio viešo kelio ar tako. Štai apie žemės sklypus Žemés istatyme yra aiškiai pasakyta, kad jei sklypas yra apsuptas kitų savininkų sklypų, tai atkirstojo sklypo savininkas turi teisę gauti privažiavimą i savo teritoriją.

Taigi nors Lietuvoje tradiciškai yra ịprasta laisvai naudotis atviru kraštovaizdžiu rekreaciniais tikslais, tačiau tokia teisė nèra aiškiai ịtvirtinta ịstatymuose. Tam tikros galimybės lankytis atvirame kraštovaizdyje reglamentuojamos Miškų,Žemes ir Turizmo ịstatymuose ir Rekreaciniu teritoriju naudojimo, planavimo ir apsaugos nuostatuose, tačiau apie universalią prieigos teisę niekur nerašoma. Plačiausios lankymosi galimybès nustatytos rekreacinèse teritorijose, kurios užfiksuojamos teritorijų planavimo dokumentuose, tačiau toks prieigos teisès teritorinis fiksavimas yra nepriimtinas dèl to, kad tai iš karto smarkiai apriboja žmonių galimybes patiems spręsti, kur jie nori užsiimti rekreacine veikla - sprendimą už juos priima planuotojai ir valdininkai, be to, pati aplinka kinta, o patys planai sensta ir nèra privaloma perimti ankstesnių teritorijų planavimo dokumentų sprendinius.

\section{Užsienio šalių patirtis, reglamentuojant kraštovaizdžio prieigos teises}

Nagrinejjant visuomenès teises $\mathfrak{i}$ atvirą kraštovaizdị užsienio valstybėse, galima pastebėti du visiškai skirtingus šio klausimo traktavimo būdus. Vienu atveju visuomenè turi plačias teises būti atvirame kraštovaizdyje ir jame judèti, kitu atveju - šios teisès labai apribojamos. Geriausiai šiuos du priešingus atvejus iliustruoja Skandinavijos valstybės ir Škotija, kur egzistuoja universali prieigos tiesè, bei Anglija ir Velsas, kur prieigos teisè yra minimali. 
Skandinavijos valstybės turi keletą bendrų bruožų, kurie tiesiogiai lèmè prieigos teisès atsiradimą jose. Visų pirma, istorinès priežastys: šiose valstybėse niekada nebuvo „klasikinio“ feodalizmo epochos, o asmeninè laisvè visada buvo didele vertybè. Viena iš tokių laisves išraiškos formų buvo ir yra kiekvieno žmogaus teise (What makes Nordic ... 2008), kitaip sakant, prieigos teisè į atvirą kraštovaizdį. Antra, laisvalaikio leidimas atvirame ore yra šių valstybių kultūros dalis. Trečias svarbus dalykas, kuris turi ịtakos prieigos teisès egzistavimui ir mūsų dienomis, yra gerokai mažesnis gyventojų tankumas Skandinavijos valstybėse ir Škotijoje, palyginti su kitų Europos valstybių gyventojų tankumu (2 pav.). Tačiau prieigos teisè galioja ir tankiau apgyvendintuose šių šalių regionuose, pvz., aplink sostines. Štai Švedijoje vidutinis tankumas $22,1 \mathrm{gyv} . / \mathrm{km}^{2}$, bet jis siekia net 292,1 gyv. $/ \mathrm{km}^{2}$ Stokholmo lene. Suomijos pietuose tankumas yra 63,8 gyv. $/ \mathrm{km}^{2}$, Norvegijoje Oslo regione $-209,5$ gyv. $/ \mathrm{km}^{2}$.

Kaip kontrastas Skandinavijos valstybėms gali būti Anglija ir Velsas, kur feodalizmas ir absoliuti siuzereno nuosavybès teisè atsirado anksti. Čia net nekultivuojama žemè buvo labai saugojama daugiausia dèl to, kad žemės savininkai siekè apginti savo medžioklès ir žvejybos teises. Taigi visuomenei liko labai mažai galimybių džiaugtis gamtine aplinka, net jei ta aplinka ir nebuvo naudojama jokiai ekonominei veiklai. Pavyzdžiui, nekultivuojami ir natūralūs viržynai, uolynai, aukštikalniu pievos yra aptveriami ir apsmaigstomi draudžiamaisiais ženklais. Nulipti nuo vieškelio ir žengti žingsni ant tokios žemès - nusikalstamas ịsibrovimas. Už tokių tvorų yra atsidūrę daugybè visuomeninę reikšmę turinčiu ir neparasto grožio gamtinių teritorijų.

Prieigos teisès juridiniai ịtvirtinimo būdai. Skandinavijos ir Škotijos prieigos teisès yra ịvirtintos labai skirtingai (1 lentelè). Štai Norvegijoje allemannsretten kiekvieno žmogaus teisé - yra ittvirtinta specialiu įstaty$\mathrm{mu}-1957 \mathrm{~m}$. Aktu dèl rekreacijos atvirame ore (Act of 28 June ... 1957). Šios teisès taikymą vandens telkiniuose dar patikslina Vandens šaltiniu aktas (Act No. 28 of 24 November ... 2000), o saugomose teritorijose - Gamtos apsaugos aktas (Act of 19 June ... 1970).

Švedijoje allemansrätten yra ịtvirtinta šios šalies Konstitucijoje nuo 1994 metu (What is the Right ... 2007). Tikslesnis šios teisès reguliavimas ar apribojimas yra ịtvirtintas kituose įstatymuose, kurie reglamentuoja skirtingas veiklos sritis ir nurodo šios teisès ribas. Svarbiausias iš tokių įstatymų yra Švedijos aplinkosaugos kodeksas (Swedish Environmental ... 1998). O įvairiais neaiškiais atvejais pasitelkiama teismų praktika.

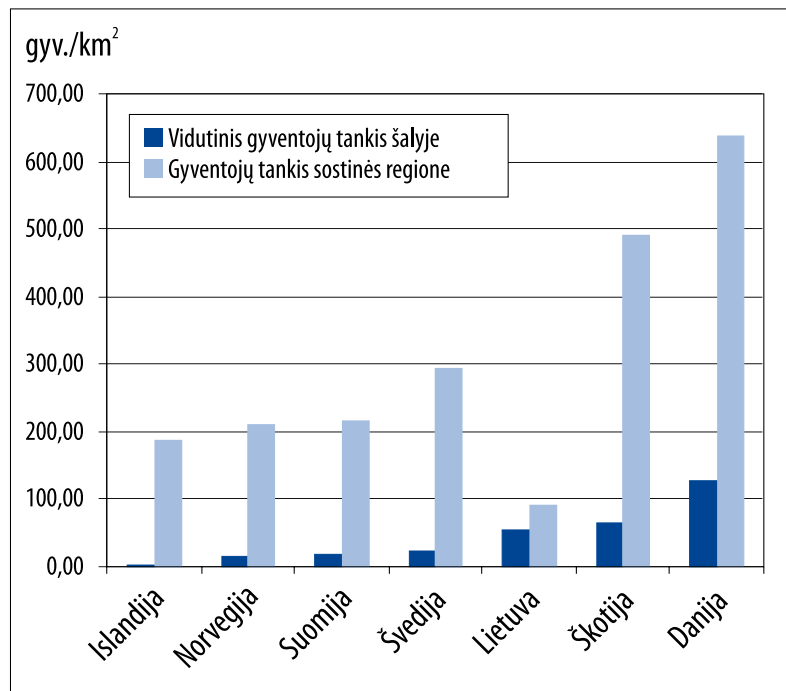

2 pav. Lietuvos, Skandinavijos valstybių ir Škotijos tankio ir sostinés regiono gyventojų vidutinio tankio palyginimas Fig. 2. Population density - average in the country and in capital regions of Lithuania, Scandinavia and Scotland

Suomijoje jokamiehenoikeudet (kiekvieno žmogaus teisè) yra savaime suprantamas dalykas, jos apribojimo atvejai nurodyti Gamtos apsaugos istatyme (The Nature ... 1996), Vandens istatyme (The Water Act ... 1961) ir Vandens transporto istatyme (The Water Traffic ... 1996). Danijoje prieigos teisè yra reglamentuojama Gamtos apsaugos istatymu (Access to coast ... 2008).

Škotijoje tradicinè prieigos teise buvo įtvirtinta $2003 \mathrm{~m}$. žemés reformos istatymu (Land Reform ... 2003). Jo nuostatos išaiškintos ne tokia sudètinga teisine kalba Elgesio atvirose erdvese kodekse (Scottish Outdoor ... 2008).

1 lentelè. Prieigos teisès įtvirtinimo būdai Skandinavijoje ir Jungtinèje Karalystejje

Table 1. Juridical means of implementing the right of access in Scandinavia and the United Kingdom

\begin{tabular}{ll}
\hline Šalis & Prieigos teisės įtvirtinimas \\
\hline Suomija & $\begin{array}{l}\text { Tradicinè teisè, numatyti tik jos apribojimai } \\
\text { tam tikrais atvejais }\end{array}$ \\
\hline Švedija & Konstitucija \\
\hline Norvegija & Aktas dèl rekreacijos atvirame ore \\
\hline Danija & Gamtos apsaugos įstatymas \\
\hline Škotija & žemės reformos ịstatymas \\
\hline Anglija & $\begin{array}{l}\text { Dalinè ribota prieigos teisè, paremta } \\
\text { tradicinėmis kelio ir bendruomeninemis } \\
\text { teisėmis, bei jos išplètimas pagal Kaimo } \\
\text { kraštovaizdžio ir kelio teisių akta }\end{array}$ \\
\hline Velsas &
\end{tabular}


Anglijoje ir Velse nèra universalios prieigos teisès. Keliauti pėsčiomis ar dviračiu užmiesčio teritorijose leidžia tik ten egzistuojančios atskiros kelio ir įvairios bendruomeninès teisès. Deja, šios teisès apima palyginti nedidelę šių šalių teritorijos dali.

Taip pat Anglijoje ir Velse pagal Senoves monumenty ir archeologiniu vietoviu istatyma (Ancient Monuments ... 1979) visuomenè turi teisę patekti prie bet kurio monumento, kuris yra Valstybès sekretoriaus žinioje. Panašiu prieigos leidimų buvo numatyta ir ịstatymuose, reglamentuojančiuose ypatingo mokslinio intereso bei išskirtinio gamtinio grožio vietoves (Wildlife and Countryside Act 1981, National Parks and Access to the Countryside Act 1949).

Dar dalis Anglijos ir Velso teritorijų yra pasiekiamos visuomenei dèl jas valdančių subjektų geranoriškumo žemès savininkai ir valdytojai (pvz., Miškų komisija) gali suteikti prieigos teises savo valdomoje žemèje. Tačiau tokị geranoriškumą parodè labai mažai privačių žemès savininkų, daugiausiai tai buvo įvairios labdaringos ir aplinkos apsauga besirūpinančios organizacijos.

Prieigos teisès esmè Skandinavijos valstybèse ir Škotijoje yra vienoda: kiekvienas žmogus, jei jis elgiasi atsakingai, nedaro žalos gamtai, netrukdo žemès savininkams ir kitiems keliautojams, gali būti ir užsiiminèti tam tikra rekreacine veikla atvirame kraštovaizdyje. Ivairūs įstatymų aktai šią teisę patikslina ir apibrèžia, kokioje žemejje galioja prieigos teisè (2 lentelè), kokiomis transporto priemonemis galima judèti, kokia rekreacine veikla galima užsiimti, kada ši teisè gali būti apribojama, kokios yra žemės savininkų pareigos ir teisès šiuo atveju.

Pagrindinę galimybę lankytis Anglijos ir Velso kraštovaizdyje ilgą laiką suteikè minètos kelio teisès. Juridiškai visi keliai ir taikai, kuriems galioja kelio teisé, yra prilyginami bet kuriam kitam valstybiniam keliui (net jei tai būtų tik pėsčiųjų takelis). Tokių kelių ir takų yra apie 190 tūkst. km. Visi tie takai yra prižiūrimi tos pačios vietos institucijos, kuri rūpinasi ir kitais krašto keliais. Kelio teisès yra įvairios: tik pėsčiųjų arba raitelių (arkliu arba dviračiu) ir pėsčiųjų bei galiausiai - visų rūšių transporto. Daugiausiai yra pėsčiųjų takų - 78 \% (What are Public ... 2008). Žmonès dar gali tokiu taku važiuoti invalido vežimèliu, vestis šuni, sustoti pakelèje pailsèti ir užkąsti, apeiti kliūti - ir tai viskas, kas yra leidžiama.

Natūroje šie keliai yra paženklinti atitinkamais ženklais, taip pat galima įsigyti specialių žemèlapių. Takas gali tapti viešo naudojimo taku, jei visuomenè jị naudoja ilgą laiką be pertraukos (daugiau kaip 20 metų), daug
2 lentelè. Būdingas prieigos teisès teritorinis taikymas ir ribojimas Skandinavijoje ir Škotijoje

Table 2. Common territorial application and restriction of the right of access in Scandinavia and Scotland

\begin{tabular}{|c|c|}
\hline $\begin{array}{l}\text { Teritorijos, kurioms } \\
\text { taikoma prieigos teise }\end{array}$ & $\begin{array}{l}\text { Teritorijos, kurioms taikomi } \\
\text { prieigos teisès ribojimai }\end{array}$ \\
\hline $\begin{array}{l}\text { Nekultivuojama žemè, } \\
\text { tokia kaip: }\end{array}$ & $\begin{array}{l}\text { Kultivuojama žemè, tokia } \\
\text { kaip: }\end{array}$ \\
\hline • miškai & • pasèliai \\
\hline $\begin{array}{l}\text { - vandens telkiniai ir ju } \\
\text { pakrantès }\end{array}$ & $\begin{array}{l}\text { - miško sodmenu plantacijos } \\
\text { ir medelynai }\end{array}$ \\
\hline • kalnai ir kalvynai & - ganyklos ir pievos \\
\hline - viržynai, pelkynai, dykynès & - sodai \\
\hline $\begin{array}{l}\text { žemès ūkio laukų pakraščiai } \\
\text { ir pagrioviai }\end{array}$ & - ūkininku sodybos ir fermos \\
\hline $\begin{array}{l}\text { žemès ūkio teritorijos, pasi- } \\
\text { baigus vegetacijos periodui }\end{array}$ & $\begin{array}{l}\text { Golfo laukai ir sporto } \\
\text { irenginiai varžybų metu }\end{array}$ \\
\hline \multirow{6}{*}{$\begin{array}{l}\text { Valstybės saugomi gamtos ir } \\
\text { kultūros paveldo objektai }\end{array}$} & Karjerai \\
\hline & Atliekų tvarkymo teritorijos \\
\hline & $\begin{array}{l}\text { Krašto gynybai naudojamos } \\
\text { teritorijos }\end{array}$ \\
\hline & $\begin{array}{l}\text { Urbanizuotos ir pramoninès } \\
\text { teritorijos }\end{array}$ \\
\hline & $\begin{array}{l}\text { Teritorijos prie gyvenamuju } \\
\text { namų ar vasarnamių (tik pati } \\
\text { namų valda) }\end{array}$ \\
\hline & $\begin{array}{l}\text { Saugomos teritorijos, jei tai } \\
\text { būtina jose saugomiems } \\
\text { gamtiniams ar kultūriniams } \\
\text { objektams }\end{array}$ \\
\hline
\end{tabular}

tokių takų yra šimtmečių senumo. Ir vieną kartą atsiradusi kelio teisè nebeišnyksta. Todèl nemažai žemès savininkų, kurie leidžia naudotis visuomenei kokiu nors savo taku, būtinai iškabina skelbimus, kad takas nèra skirtas nuolatiniam viešam naudojimui arba uždaro ji vienai dienai per metus - kad nesusikurtų kelio teisé (Basics of ... 2008).

Kelio teises, kaip ir kitus su keliais susijusius dalykus reglamentuoja Keliu istatymas (Hightways Act ... 1980). Nors Anglijoje ir Velse egzistuoja nemažas kelio teisių tinklas, daug kelių, ypač lauko keliukų, yra privatūs. Eiti tokiu keliu jau yra ịstatymų pažeidimas.

Anglijos ir Velso bendruomeninès teisès (commoner's rights) - tai teisès (ganymo, žvejybos, malkavimo ir pan.), kurias turi kai kurie žmonès ịjiems nepriklausančią pagal nuosavybės teisę žemę. Panašus dalykas yra ir teisès į miestelių ir kaimų žaliuosius plotus (Town and Village Greens). Čia kalbama apie tą žemę šalia gyvenviečiu ar jose, kuri, nors ir priklauso konkrečiam savininkui, yra ilgą laiką naudojama vietinių gyventojų 
sportui, žaidimas, iškylavimui ir pan. Tai nèra tas pats, kas miestų žalieji plotai (parkai ir skverai).

Daug tokio tipo teisių yra senesnès nei rašytiniai istatymai ir net šiais laikais remiasi tradicija. Šiuo metu tokios bendruomeninès žemès Anglijoje ir Velse yra apie 572 tūkst. ha - tai tik 3,8 \% teritorijos. Tačiau daugiau kaip puse bendruomeninių žemių yra paskelbtos specialaus mokslinio intereso vietovemis (Site of Special Scientific Interest), beveik pusè yra nacionaliniuose parkuose ir trečdalis yra išskirtinio gamtinio grožio vietovès (Areas of Outstanding Natural Beauty) (Common Land ... 2008). Dabartiniu metu beveik visoje bendruomeninejje žemejje Anglijoje ir Velse taip pat pradejjo galioti ir dalinè prieigos teisé, kaip tai nustate 2000 m. Kaimo kraštovaizdžio ir kelio teisiu aktas arba dar ankstesni teisès aktai (Explanatory Notes ... 2006). Šị dalinès prieigos teisès atsiradimą bendruomeninèje žemèje lèmé vis dažnesnis tų žemių naudojimas sportui ir rekreacijai atvirame ore. Pvz., Nuosavybes įstatyme (Law of ... 1925) buvo ittvirtinta prieigos teisè bendruomeninèje žemëje, esančioje urbanizuotose teritorijose. Nacionaliniu parku ir prieigos i kaimo kraštovaizdị istatymas leido visuomenei laisvai judèti dar papildomoje dalyje atvirų erdvių (apie 50 tūkst. ha), (Explanatory Notes ... 2006).

Visai priešingai yra Skandinavijoje ir Škotijoje, kur visuomenei neprieinamų teritorijų yra gerokai mažiau nei tų, kur galioja prieigos teisè. Ši teisè pirmiausia taikoma visai nekultivuojamai žemei ir didelei daliai žemès ùkio teritorijų, kurios priskiriamos prie kultivuojamos žemès (2 lentelè). Kokia žemė yra kultivuojama, o kokia nekultivuojama, yra nustatyta anksčiau išvardintuose teisès aktuose ir visose valstybėse laikomasi to paties požiūrio. Nekultivuojama žeme laikoma kalnai, viržynai, miškai, vandens telkiniai, jūros pakrantès ir pan.

Kultivuojama žeme laikoma fermų kiemai, žemès sklypai prie namų ir vasarnamių, užstatytos teritorijos, sporto kompleksai, golfo laukai, sodai, šienaujamos pievos, pasèlių laukai, ganyklos, îvairios augalu plantacijos ir medelynai, industrinès, naudingụjų iškasenų gavybos ir panašios teritorijos, kur viešas prieinamumas trukdytų tų teritorijų naudotojams. Žiemą, kai žemé užsnigta ir sušalusi, prieigos teisè ima galioti ir žemès ūkio laukuose (pvz., Norvegijoje tai būtų nuo spalio 14 d. iki balandžio 30 d.). Taip pat naudojantis prieigos teise galima judèti laukų pakraščiais ir eiti per pievas ir ganyklas, jei tai nedaro joms žalos.

Čia iš kitų valstybių, kuriose galioja prieigos teisè, išsiskiria Danija. Šioje valstybejje miškai užima tik 15,6 \% teritorijos ir yra mažai žmogaus nepaliestos gamtos. Tie patys miškai yra iš esmès naujai išauginti, nes XIX a. pradžioje miškingumas buvo kritęs iki $2 \%$. Dauguma miškų yra privatūs ir neretai aptverti. Taigi ir prieigos teisè ištisą parą galioja tik valstybiniuose miškuose, o privačiuose miškuose galima būti nuo 7 val. ryto iki saulèlydžio ir tik ant takų. žemès ūkio teritorijose prieigos teisè galioja tik lauko keliukuose ir takuose.

Prieigos teisès turinys. Prieigos teisè Skandinavijos valstybėse ir Škotijoje galioja tik nemotorinèms transporto priemonèms. Galima eiti pèsčiomis, važiuoti dviračiu, šliuožti slidèmis, tempti roges, joti arkliu, plaukti baidare, kanoja ar valtimi, buriuoti. Motoriniais laivais galima visai laisvai plaukioti tik Suomijoje. Prieigos teise taip pat pritaikoma ir retesnems nemotorinems transporto priemonems, pvz., riedučiams ar sklandymui su aitvaru.

Leidžiama veikla (3 lentelè) apima visą spektrą užsièmimų, galimų atvirame ore: iškylavimą, deginimąsi saulèje, maudymąsi, laipiojimą uolomis, žaidimus, grybavimą ir uogavimą, vaistažolių rinkimą, gyvūnijos stebėjimą ir kitokius gamtos pažinimo užsièmimus.

Rekreaciją atvirame kraštovaizdyje sunku įsivaizduoti be stovyklavimo ir stovyklos laužo. Stovyklauti galima visur Skandinavijoje ir Škotijoje, kur galioja ir prieigos teisè. Išskyrus Daniją, kur to iš viso nebuvo galima daryti iki $2004 \mathrm{~m}$. Tais metais Miškų ir gamtos agentūra (Camping for ... 2008) suteikè teisę stovyklauti maždaug 40 miškų. Buvo sukurtas specialus puslapis (http://www.skovognatur.dk/) Miškų ir gamtos agentūros interneto svetainèje, kur galima rasti vietas, skir-

3 lentelè. Dažniausių veiklu, kurias leidžia prieigos teisè užsienio valstybèse, apibendrinimas

Table 3. Allowed activities under the right of access in foreign countries

\begin{tabular}{ll}
\hline Leidžiama veikla & Reglamentavimas \\
\hline $\begin{array}{l}\text { Judejjimo atviru krašto- } \\
\text { vaizdžiu būdai }\end{array}$ & $\begin{array}{l}\text { pésčiomis, raitomis, dviračiu, } \\
\text { nemotoriniu laiveliu, slidėmis } \\
\text { ir kitomis bevariklëmis } \\
\text { priemonemis }\end{array}$ \\
\hline $\begin{array}{l}\text { Užsièmimai atvirame } \\
\text { kraštovaizdyje }\end{array}$ & $\begin{array}{l}\text { iškylavimas, deginimasis saulèje, } \\
\text { maudymasis, laipiojimas } \\
\text { uolomis, žaidimai, vaistažoliu } \\
\text { ir uogu rinkimas, gamtos } \\
\text { pažinimas }\end{array}$ \\
\hline Stovyklavimo laikas & 1-2 dienos \\
\hline Stovyklautoju skaičius & 2-3 palapinės \\
\hline Stovyklos atstumas nuo & nustatomas vizualiai, tiesiog turi \\
pastatu & nesimatyti ir nesigirdèti arba \\
& 50-150 metrų \\
\hline Laužai & ribojami \\
\hline
\end{tabular}


tas stovyklauti. Ši eksperimentą buvo numatyta tęsti iki 2006 metų, bet kadangi gauta daug teigiamų atsiliepimų ir jokių skundų, ši tvarka galioja iki šiol.

Statyti palapinę ir pasilikti toje pačioje vietoje galima daugiausiai dviem dienom. Taip pat tuo pačiu laikotarpiu galima prisišvartuoti prie privačios prieplaukos, jei šalia nèra namo.

Palapinių ar žmonių skaičius aiškiai nurodytas tik keliose valstybèse. Švedijoje palapinių negali būti daugiau kaip trys. Danijoje apsistoti galima vienai nakčiai ir pastatyti ne daugiau kaip dvi palapines, kurios negali būti didesnès nei trijų vietų. Tačiau bet kuriuo atveju prieigos teise negali pasinaudoti labai didelès žmoniu grupès, jie jau turi susitarti su žemès savininku.

Visose šiose valstybėse sutariama, kad stovyklautojų negali matytis nuo gyvenamųjų namų, taip pat neturi girdètis jokių garsų. Tikslus atstumas normuojamas ne visur. Norvegijoje ir Islandijoje (Outdoor recreation 2008) jis yra $150 \mathrm{~m}$. Danijoje iškylauti ir maudytis galima ne arčiau kaip 50 m nuo gyvenamụjų namų.

Dẻl laužų bendros nuomonès šiose valstybèse nèra. Laužus kurti galima Švedijoje ir Škotijoje, jei nėra paskelbtas visuotinis laužų draudimas esant dideliam miškų gaisringumui. Norvegijoje laužų negalima kurti nuo balandžio $15 \mathrm{~d}$. iki rugsėjo $15 \mathrm{~d}$. miško zonoje (Allemansret ... 2008). Suomijoje laužui kurti reikia prašyti žemès savininko leidimo, bet didelio gaisringumo metu jie irgi būna visur uždrausti (The Fire ... 1975). Danijoje laužai uždrausti iš viso. Vienu žodžiu, laužai yra iš dalies toleruojami, bet žmonès yra skatinami naudotis turistinèmis viryklèmis.

Visose nagrinëjamose valstybėse besinaudojantiems prieigos teise keliami ir tam tikri elgesio reikalavimai. Svarbiausia taisyklè yra - netrukdyk ir nenaikink. Tai reiškia, kad būtina gerbti žemès savininkų privatumą ir nuosavybę, negalima jiems sukelti kokių nors nepatogumų užsiimti ekonomine veikla. Taip pat privalu saugoti gamtą ir nedaryti jokios žalos jai.

Žemès savininkai savo ruožtu negali kaip nors kliudyti žmonèms patekti ị teritorijas, kuriose galioja prieigos teisè. Tai yra jie negali statyti tvorų ir kasti griovių, kurie specialiai skirti lankymosi galimybėms apriboti, bei iškabinti draudžiamųjų skelbimų (tokių kaip privati valda, iejjimo nèra ir pan.). Aptikęs tokias tvoras ar skelbimus žmogus turi teisę apie juos pranešti vietos savivaldybei ar kitai atsakingai institucijai, kuri îpareigoja savininkus tokias tvoras ir skelbimus pašalinti. Esant būtinybei, gali būti pasitelkta ir policijos pagalba.

Jei tvoros yra pastatytos galvijams aptverti ir tai trukdo pasiekti kokị nors lankomą kultūros ar gamtos objektą, savivaldybė gali ịpareigoti savininką įrengti vartus ar lipynę.

Taip pat žemès savininkai negali uždrausti judèjimo nemotorinèmis transporto priemonèmis ir privačiais keliais.

Žemès savininkai turi teisę išprašyti iš savo žemès žmones, kurie elgiasi netinkamai, taip pat pareikalauti ir žalos atlyginimo. Norvegijoje žemės savininkai turi teisę rinkti užmokestị už stovyklavimą jų žemèje, tačiau šis užmokestis turi būti proporcingas savininko išlaidoms rekreacinei vietovei įrengti. Jei kokia nors vietovė yra ypač gausiai lankoma, savininkas kartu su savivaldybe turi teisę nustatyti lankymosi taisykles.

Prieigos teisès ribojimas. Prieigos teisè yra ribojama arba iš viso netaikoma, kai kalbama apie dideles žmonių grupes ar organizuotas varžybas (tokias kaip orientavimosi, dviračių ar baidarių ralius, lenktynes ir pan.). Pagal Švedijos Aplinkosaugos kodeksą organizuota rekreacinè veikla turi būti nutraukta, jei ima daryti žalą gamtai ar labai trukdyti žemės savininkams. Taip pat ir Suomijoje, jei organizuojamas renginys atvirame kraštovaizdyje, kuriame dalyvauja daug žmonių, būtina gauti žemès savininko sutikimą. Škotijoje galima naudojantis prieigos teise organizuoti rekreacinę veiklą ir gauti už tai užmokestị, jei toji veikla nesiskiria nuo tos veiklos, kuria užsiimtų pavieniai žmonès, pvz., gidas gali vesti grupę žmonių per kalnus.

Saugomose teritorijose prieigos teisè taip pat gali būti apribojama. Norvegijoje tokio ribojimo atvejai nurodyti Gamtos apsaugos įstatyme. Švedijoje - jau minètame Aplinkosaugos kodekse. Nacionaliniuose parkuose vèlgi gali galioti specialios lankymosi taisyklès.

Vietos savivaldybès gali apriboti prieigos tiesę ir kitose gamtinèse teritorijose, nors jos gali ir neturèti apsaugos statuso. Taip pat ir savininko prašymu savivaldybès gali imti taikyti apribojimus, jei tam tikroje vietoje susidaro per daug dideli žmonių srautai, kurie ima kenkti aplinkai ar savininko ekonominei veiklai.

Prieigos teisè vandens telkinių pakrantèse. Kaip atskirą atveji tikslinga paminèti prieigos teisę vandens telkinių pakrantèse. Štai Norvegijoje draudžiama statyti pastatus, statinius ir tvoras arčiau kaip $\mathbf{1 0 0} \mathbf{~ m}$ nuo jūros kranto. Taip pat čia draudžiama smulkinti sklypus, juos dalimis nuomoti. Tai nustatyta Planavimo ir statybos akte (Act of 14 ... 1985). Žinoma, šios nuostatos netaikomos jau užstatytoms teritorijoms, taip pat teritorijoms, kurioms parengti zonavimo, krantų tvarkymo planai, savivaldybių bendrieji planai ir juose yra numatyti statybos ar kasybos darbai. Išimtis taikoma ir statiniams, kurie reikalingi gynybai, žemės ūkiui, 
žuvininkystei, komunalinėms reikmėms ir pan. Iškilus abejonèms dèl šių nuostatų taikymo, sprendimą priima apskrities valdytojas. Taigi šis draudimas statyti $100 \mathrm{~m}$ zonoje Norvegijoje turi daug išimčių, ypač draudimą silpnina leidimas jo nepaisyti pagal parengtus bendruosius planus - tuo buvo lengvai piktnaudžiaujama, ypač Oslo fiordo regione (T-1048 National ... 1993). Tačiau net ir pastatęs pastatus $100 \mathrm{~m}$ zonoje, savininkas vis tiek negali tverti tvorų ir drausti vaikščioti pakrante.

Švedijos jūros, ežerų ir upių pakrantès taip pat turi specialų apsaugos statusą, kuris galioja po $100 \mathbf{~ m} i$ kranto ir ị vandens pusę. Šis statutas visų pirma skirtas tam, kad būtų užtikrintas viešas pakrančių naudojimas ir sudarytos sąlygos augmenijai bei gyvūnijai klestèti. Vienareikšmiškai draudžiama „privatizuoti“ krantus, statant tvoras. Tačiau prieigos teisè gali būti ribojama savivaldybės ar leno administracijos, ypač paukščių ir gyvūnų buveinių apsaugos vietose.

Danijoje yra specialus jūros pakrančių reglamentas: visa žemè $\mathbf{2 0}$ m nuo jūros kranto ị sausumos pusę priklauso valstybei ir yra atvira visuomenei. Išimtys yra kai kurie draustiniai, kur lankytis neleidžiama.

Deja, skirtingai nuo Skandinavijos valstybių ir Škotijos, upès ir ežerai Anglijoje ir Velse yra dar mažiau prienami nei sausumos teritorijos. Vandens turizmas baidaremis ar kanojomis ir netgi maudymasis čia gali vykti tik $2 \%$ visų galimų naviguoti vandens telkinių (Freedom to ... 2008). Anglijoje ir Velse nèra ir bendros teisès vaikščioti jūros pakrante. O tose vietose, kur leidžiama, nustatyta daugybe vietos ịstatymų ar net neformalių susitarimų.

Tačiau pastaraisiais metais ir Jungtinèje Karalystèje ịvyko tam tikrų labai svarbių pokyčiu prieigos teisès išplètimo linkme. 2000 metais buvo priimtas jau minètas Kaimo kraštovaizdžio ir kelio teisiu istatymas (Countryside and ... 2000). Šiuo aktu buvo įtvirtinta teisè klajoti - jeiti ir pasilikti (Jus Spatiendi) kai kuriose nekultivuojamose viržynų, durpynų, kalvų ir aukštikalnių (didesnių nei $600 \mathrm{~m}$ ) teritorijose, taip pat teritorijose, kuriose tuo metu galiojo bendruomeninès teisès. Miškai ir vandenys šiame ịstatyme, deja, neaptarti. Šis istatymas buvo igyvendinamas etapais iki $2005 \mathrm{~m}$., rengiant planus, kuriuose nurodomos laisvai prieinamos teritorijos, taip pat revizuojant esamus viešus takus, ieškant galimybių naujiems takams nutiesti. Vèliau Miškų komisija savo iniciatyva prieigos teisę suteikè ir ị savo valdomus miškus.

Tai, kad dauguma teritorijų, kurioms taikoma prieigos teisè, turi būti pažymètos specialiuose planuose, smarkiai apribojo tą pačią prieigos teisę: žmogus neži- no, ar gali laisvai judèti teritorija, pirma neịsigijęs specialių žemèlapių arba nepasitikrinęs specialioje interneto svetainëje (http://www.countrysideaccess.gov. uk/ things_to_do/open_access). O vietovèje turi dairytis specialių ženklų, žyminčių laisvos prieigos teritorijas.

Skandinavijos valstybèse universali prieigos teisè tą leidžia daryti. Žinoma, Anglijos ir Velso atveju Kaimo kraštovaizdžio ir kelio teisiu isstatymas yra didelè pažanga. Nors jis ir neleidžia kurti laužų, maudytis ir plaukioti bet kokiu laiveliu ne jūros vandenyse, važiuoti bet kokia transporto priemone (tai reiškia ir dviračiu) bei stovyklauti. Vienintelès galimos veiklos yra vaikščiojimas, bėgiojimas, paukščiu stebejimas, laipiojimas uolomis, šuns vedžiojimas pavadžiu. Teritorijos, kuriose galioja prieigos teisè, yra dispersiškai pasiskirsčiusios po visą Anglijos ir Velso teritoriją ir ištisinių juostų ar masyvų nesudaro.

Vandens telkinių ir jų pakrančių prieinamumas taip pat turètų pagerèti. Aplinkos, maisto ir kaimo reikalų departamentas $2008 \mathrm{~m}$. parengè Jüros bilio projekta, kuriame numatyta išplèsti visuomenès teises į vaikščiojimą jūros pakrante (Draft Marine ... 2008) - sukurti visos Anglijos pakrantės maršrutą ir rasti teritorijų, tinkamų rekreacijai atvirame ore.

Velse šiuo metu valdžios institucijos taip pat siekia išplèsti viešąją prieigos teisę pakrantėse. Teisès vaikščioti upių, ežerų ir kanalų pakrantèmis taip pat dar nèra, nors visuomeninès organizacijos dirba šioje srityje, siekdamos atitinkamų îstatymų prièmimo.

Apžvelgus Skandinavijos ir Jungtinès karalystès istatymus, reguliuojančius kraštovaizdžio visuomeninị prienamumą, matyti, kad prieigos teisès sèkmingai egzistuoja daugeli metų Skandinavijos valstybèse ir Škotijoje bei teikia visokeriopą naudą jų gyventojams ir svečiams. Jose prieigos teisè yra universali - tai yra neitvirtinta jokiuose teritorijų planavimo dokumentuose. İstatymais nustatoma, kokią veiklą apima prieigos teisè ir kur ji negalioja. Teritorijos, kur prieigos teisé negali būti taikoma, užima daug kartų mažesni plotą nei teritorijos, kur ši teisė galioja. Anglijoje ir Velse yra priešingai - dalinès ir labai ribotos prieigos teisès taikomos tik keliems procentams šių šalių teritorijos. Tačiau net ir šiose šalyse pastarajji dešimtmeti prieigos teisès yra plečiamos visuomenès naudai.

\section{Pasiūlymai, kaip įtvirtinti Lietuvos visuomenès teises ị atvirą kraštovaizdi}

Lietuvos kraštovaizdis, lietuvių laisvalaikio leidimo būdai bei gyventojų tankis $\left(54,2 \mathrm{gyv} . / \mathrm{km}^{2}\right)$ leidžia eg- 
zistuoti universaliai prieigos teisei ir mūsų šalyje. Apibrèžta įstatymais, o ne planavimo dokumentais prieigos teisè užtikrintų atviro kraštovaizdžio prieinamumą nepriklausomai nuo nuosavybès formos. Atkūrus Nepriklausomybę, perejus nuo išimtinai valstybinès prie privačios žemès nuosavybès, tokia atsvara būtina, jei norime, kad Lietuvos visuomenè ir ateityje galètų naudotis kraštovaizdžio vertybėmis rekreacijos ir pažinimo tikslais. Priešingu atveju Lietuvoje susiklostys situacija, panaši i tą, kuri yra Anglijoje ir Velse, kai kraštovaizdžio grožis ir gamtinès vertybès taip pat tampa privačia gèrybe.

Universalią kraštovaizdžio prieigos teisę būtų tikslinga įtvirtinti Turizmo įstatyme. Taip dabartinis šio ịstatymo susitelkimas ị turizmo paslaugų teikimo reglamentavimą būtų papildytas - jame būtų ginamos visuomeninès teisès ị atvirą kraštovaizdị. Turizmo ịstatyme būtų apibrežzta prieigos teisès esmè, kaip ir Skandinavijos valstybèse - teisè laisvai judèti ir būti atvirame kraštovaizdyje, nedarant žalos žemès savininkams ir aplinkai. Kartu šiame istatyme tikslinga iš karto nustatyti ir prieigos teisès turini (kokia veikla yra leidžiama ir kokị laiko tarpą galima likti vienoje vietoje) bei žemès savininkų teises ir pareigas - šie dalykai yra labai svarbūs ir neatskiriami, jei norima garantuoti Lietuvos kraštovaizdžio visuomeninį prieinamumą.

Prieigos tiesès ribojimo atvejai galètų būti nustatyti tame pačiame Turizmo įstatyme arba kituose istatymuose, kuriuose reglamentuojamos atskiros veiklos sritys. Pavyzdžiui, Saugomų teritoriju isstatyme galètų būti nustatyti šios teisès ribojimo atvejai, kai to reikia gyvosios gamtos apsaugai.

Bendruoju atveju prieigos teisė Lietuvoje turètų leisti atvirame kraštovaizdyje užsiimti tokia rekreacine veikla kaip vaikščiojimas, bejgiojimas, judejjimas nemotorinèmis transporto priemonėmis, lauko žaidimai, iškylavimas, stovyklavimas (t. y. nakvojimas palapinëje), maudymasis ir pan. Laužai galètų būti kuriami tik tada, jei tai yra saugu, naudojant nukritusias šakas bei panaikinat laužavietės žymes. Buvimo toje pačioje vietoje laikas ir žmonių skaičius irgi gali būti ribojamas kitų valstybių pavydžiu iki 2 parų ir iki 3 palapinių.

Teritorijos, kurioms negaliotų prieigos teisè, būtų užstatytos teritorijos (išskyrus bendro naudojimo), sodybos ir sodai, karjeru teritorijos, sporto lauku bei aikštelių teritorijos varžybų metu, naudinguju iškasenų gavybos teritorijos, karinès teritorijos ir žemès ūkio laukai vegetacijos metu (išskyrus pievas ir ganyklas), taip pat kitos jautrios augalų plantacijos.
Žemès savininkams turètų būti draudžiama riboti prieigos teisę statant barjerus ir iškabinant draudžiamuosius skelbimus. Tačiau netinkamai besielgiantys žmonès privačioje žemèje prarastų prieigos teisę - žemès savininkas turètų neginčijamą teisę tokius žalą darančius žmones išprašyti iš savo žemès.

Taigi būtų pagaliau padètas pagrindas Lietuvos kraštovaizdžiui išsaugoti visuomenei. Kitaip rizikuojama iš viso prarasti didelę dalị Lietuvos kraštovaizdžio rekreacinio potencialo.

\section{Išvados}

1. Šiuolaikiniame pasaulyje, kur daugelis žmonių gyvena miestuose ir dirba didelio judrumo nereikalaujančius darbus, galimybė užsiimti rekreacine veikla atvirame kraštovaizdyje tampa ypač svarbi. Lietuvoje laisvalaikio leidimas gamtoje turi gilias tradicijas ir yra visai iprasta laivai judèti kaimo kraštovaizdžiu (aplenkiant pasèlių laukus) ir miške, plaukioti upemis ir ežerais, stovyklauti ir pan.

2. Nepaisant šių laisvalaikio leidimo tradicijų, Lietuvoje nèra ịstatymais įtvirtintinos universalios prieigos teisès ị atvirą laukų, miškų ir vandenų kraštovaizdị.

3. Universalios prieigos ị kraštovaizdį teisès yra tradicinès ir jau ittvirtintos įstatymais Skandinavijos valstybèse bei Škotijoje. Čia šios teisès puikiai funkcionuoja ir nesukelia didelių konfliktų tarp žemès savininkų ir visuomenès.

4. Priešinga situacija yra Anglijoje ir Velse, kur visuomenei prieinama tik labai nedidelè kraštovaizdžio dalis. Tačiau ir čia pastaraisiais metas siekiama atvirą kraštovaizdi padaryti prieinamesnę visuomenei.

5. Kuo toliau, tuo labiau Lietuvoje kraštovaizdis tampa privatus - ne tik kaip gamybos priemoné, bet ir pats kraštovaizdžio grožis ir visuomenine verte tampa privačiu gèriu. Lietuva šiuo metu yra savotiškoje pusiaukelèje: iš vienos pusès yra artėjimo prie angliško modelio tendencija, iš kitos pusès yra visos prielaidos ittvirtinti prieigos teisę Lietuvoje.

6. Atsižvelgiant ị didžiulę kraštovaizdžio visuomeninę vertę, rekreacijos atvirame ore svarbą šalies pažinimui ir sveikam gyvenimo būdui, Lietuvos gyventojų tankumą bei tradicijas, būtina ir mūsų šalyje įstatymu įtvirtinti universalią prieigos teisę. Tai galètų būti atliekama pakeičiant ir papildant dabar galiojantị $T u$ rizmo įstatymą. 


\section{Literatūra}

Access to coast and forrest [interaktyvus]. 2008. Visit Denmark [žiūrèta 200808 20]. Prieiga per internetą: $<$ http://www. visitdenmark.com>.

Act No. 82 of 24 November 2000 relating to river systems and groundwater (Water Resources Act) [interaktyvus]. 2000. Ministry of Petroleum and Energy [žiūrèta 200808 19]. Prieiga per internetą: $<\mathrm{http} / / /$ www.regjeringen.no $>$.

Act of 14 June 1985 No. 77 the Planning and Building Act [interaktyvus]. 1985. The Ministry of the Environment and the Ministry of Local Government and Regional Development [žiūrèta 200808 25]. Prieiga per internetą: <http://www. regjeringen.no>.

Act of 19 June 1970 No.63 relating to nature conservation [interaktyvus]. 1970. The Ministry of the Environment [žiūrèta 200808 19]. Prieiga per internetą: <http://www.regjeringen.no>.

Act of 28 June 1957 No.16 relating to outdoor recreation [interaktyvus]. 1957. The Ministry of the Environment [žiūrèta 200808 19]. Prieiga per internetą: $<$ http://www.regjeringen.no>.

Allemansret / Allemansrätt ("Everyman's right") [interaktyvus]. 2008. The Scandinavia Files [žiūrèta 200808 20]. Prieiga per internetą: $<$ http://www.pinetreedevelopment.net/scandinavia/allemansratt.php $>$.

Ancient Monuments and Archaeological Areas Act 1979 [interaktyvus]. 1979. Ministry of Justice, the UK Statute Law Database [žiūrèta 200808 26]. Prieiga per internetą: $<$ http://www.statutelaw.gov.uk>.

Basics of footpath law [interaktyvus]. 2008. Rambler's Asocciation [žiūrèta 200808 26]. Prieiga per internetą: <http:// www.ramblers.org.uk>.

Camping for the Quiet Forest Hiker [interaktyvus]. 2008. Danish Ministry of the Environment Denmark [žiūrèta 200808 20]. Prieiga per internetą: $<\mathrm{http}: / / w w w . m i m . d k>$.

Common Land. Facts and figures [interaktyvus]. 2008. Department for Environment, Food and Rural Affairs (Defra) [žiūrèta 200808 26]. Prieiga per internetą: < http://www. defra.gov.uk>.

Countryside and Rights of Way Act 2000 [interaktyvus]. 2000. Ministry of Justice, the UK Statute Law Database [žiūrèta 200808 25]. Prieiga per internetą: <http://www.statutelaw. gov.uk>.

Draft Marine Bill [interaktyvus]. 2008. HM Government [žiūrèta 200808 25]. Prieiga per internetą: <http://www.defra. gov.uk>.

Dringelis, L. 2001. Teisiniai ir norminiai dokumentai, reguliuojantys miesto želdynų sistemos planavimą, Urbanistika ir architektūra XXV(2): 63-70.

Dringelis, L. 2003. Žemès privatizavimas ir miestu viešojo naudojimo zonų urbanistinis formavimas, Urbanistika ir architektūra XXVII(4): 163-169.

Explanatory Notes to Commons Act 2006 [interaktyvus]. 2006. Department for Environment, Food and Rural Affairs (Defra) [žiūrèta 200808 26]. Prieiga per internetą: <http://www. opsi.gov.uk>.

Explanatory Notes to Countryside And Rights Of Way Act 2000 [interaktyvus]. 2000. Office of Public Sector Information [žiūrèta 200808 26]. Prieiga per internetą: <http://www. opsi.gov.uk>.
Freedom to roam [interaktyvus]. 2008. Wikipedia [žiūrèta 2008 08 26]. Prieiga per internetą: <http://en.wikipedia.org $>$.

Grecevičius, P. 1998. Architektūrinio švietimo ir rekreacinès architektūros specialistų rengimo galimybių bei tikslingumo Lietuvos Vakarų regione analizè, Urbanistika ir architektūra XXIV(3): 127-128.

Grecevičius, P.; Marčius, R. 2006. Rekreacinio kraštovaizdžio erdvinès struktūros formavimo strategijos aspektai stiprinant Lietuvos kultūrinį identitetą Baltijos šalių kontekste, Urbanistika ir architektūra XXX(2): 87-97.

Highways Act 1980 [interaktyvus]. 1980. Ministry of Justice, the UK Statute Law Database [žiūrèta 200808 26]. Prieiga per internetą: <http://www.statutelaw.gov.uk $>$.

Jakovlevas-Mateckis, K. 2006. Miesto želdynų problemos ir jų socialinè paskirtis, Urbanistika ir architektūra XXX(1): 3-14.

Land Reform (Scotland) Act 2003 [interaktyvus]. 2003. Office of Public Sector Informatikon [žiūrèta 200808 25]. Prieiga per internetą: <http://www.opsi.gov.uk>.

Law of Property Act 1925 [interaktyvus]. 1925. Ministry of Justine, the UK Statute Law Database [žiūrèta 200808 26]. Prieiga per internetą: <http://www.statutelaw.gov.uk>.

LR Baudžiamasis kodeksas, Valstybès žinios 89-2741, 200010 25 .

Mačerinskienè, A. 2001. Turizmo traukos potencialo analizè Lietuvoje naudojant GIS, Urbanistika ir architektūra $\mathrm{XXV}(1): 27-33$.

Miškų i̇statymas, Valstybès žinios 35-1161, 20010425.

Outdoor recreation [interaktyvus]. 2008. Iceland today: Iceland travel informatikon [žiūrèta 200808 20]. Prieiga per internetą: $<$ http://www.icelandtoday.is $>$.

Rekreacinių teritorijų naudojimo, planavimo ir apsaugos nuostatai, Valstybès žinios 18-554, 20040203.

Scottish Outdoor Access Code [interaktyvus]. 2008. Outdoor Access Scotland Website [žiūrèta 2008-08-27]. Prieiga per internetą: <http://www.outdooraccess-scotland.com>

Specialiosios žemės ir miško naudojimo sąlygos, Valstybès žinios 22-652, 19920810.

Stauskas, V. 2006. Miestų žaliosios erdvės socialinių ir ekonominių interesų balanso aspektu, Urbanistika ir architektūra XXX(1): 15-18.

Swedish Environmental Code [interaktyvus]. 1998. Government offices of Sweden [žiūrèta 2008-09-02]. Prieiga per internetą: <http://www.sweden.gov.se>.

T-1048 National Policy Guidelines for planning in coastal and marine areas in the Oslofjord region [interaktyvus]. 1993. The Ministry of the Environment [žiūrèta 200808 25]. Prieiga per internetą: <http://www.regjeringen.no $>$.

The Fire and Rescue Services Act 559/1975 (Lag om brand-och räddningsväsendet) [interaktyvus].1975. Finlex [žiūrèta 200808 19]. Prieiga per internetą: <http://www.finlex.fi>

The Nature Conservation Act 1096/1996 [interaktyvus]. 1996. Ministry of the Environment [žiūrèta 200808 19]. Prieiga per internetą: $<$ http://www.finlex.fi $>$.

The Water Act [interaktyvus]. 1961. Ministry of the Environment [žiūrèta 200808 19]. Prieiga per internetą: <http:// www.finlex.fi/>. 
The Water Traffic Act 463/1996 (Sjötrafiklag 20.6.1996/463) [interaktyvus].1996. Finlex [žiūrèta 2008-08-19]. Prieiga per internetą: <http://www.finlex.fi>.

Turizmo įstatymas, Valstybès žinios 123-5507, 20021224.

Tutlytė, J. 2000. Rekreacinès architektūros vertinimo kriterijai, Urbanistika ir architektūra XXIV(4): 176-182.

What are Public Rights of Way [interaktyvus]. 2008. Natural England [žiūrèta 200808 26]. Prieiga per internetą: <http:// www.countryside.gov.uk>.

What is the Right of Public Access? [interaktyvus]. 2007. Swedish environmental protection agency [žiūrèta 200808 19]. Prieiga per internetą: <http://www.naturvardsverket.se>

What makes Nordic countries a unity? [interaktyvus]. 2008. FAQ Archives [žiūrèta 200808 20]. Prieiga per internetą: $<$ http://www.faqs.org $>$.

Žemès ịstatymas, Valstybès žinios 28-868, 20040221.

\section{ANALYSIS OF ACCESS TO COUNTRYSIDE REGULATIONS IN LITHUANIA AND FOREIGN COUNTRIES}

\section{Dimindavičiūtė}

Abstract. Public rights of access to engage in recreational activities in open non-urbanized countryside in Lithuania, Scandinavia and UK are analysed in this paper. Currently there is no universal public right of access in Lithuania. On the other hand, there is no strict prohibition to walk or stay in open countryside as well. But public rights of access to the Lithuanian countryside are more and more undermined as privatization of land, forests and water is going on and land owners try to fence their properties.

The present Lithuanian legal basis that regulates public access to countryside is evaluated. Foreign experience in this field is reviewed. Scandinavian countries and Scotland adopted universal everyman's right. On the other side, public rights are very limited in England and Whales. Summarizing these different approaches and current situation in Lithuania proposals on implementing the public right of access in the Lithuanian legislature are presented.

Keywords: public right of access, Everyman's right, right to roads, open-air recreation, open countryside, recreational territories, access to water bodies and coasts.

\section{DOVILE் DIMINDAVIČIŪTE்}

Master, junior research worker, Dept of Land Use Management, Institute of Architecture and Construction, Tunelio g. 60, LT-44405 Kaunas, Lithuania. E-mail: krastotvarka@asi.lt

Master of Architecture, Kaunas Technological University (KTU), 2001. Membership: member of Lithuanian Union of Architects. Research interests: urban open public space, urban environment, master planning. 